\title{
Effect of ractopamine on physicochemical characteristics and collagen solubility in finishing pigs
}

\author{
Chanporn Chaosap ${ }^{1 *}$, Krongkaew Kaewthaworn ${ }^{2}$, Ronachai Sitthigripong ${ }^{2}$, Panneepa Sivapirunthep ${ }^{1}$, and Kamon \\ Chaweewan $^{3}$ \\ ${ }^{1}$ Department of Agricultural Education, Faculty of Industrial Education and Technology, King Mongkut's Institute of Technology \\ Ladkrabang, Bangkok 10520, Thailand \\ ${ }^{2}$ Department of Animal Production Technology and Fisheries, Faculty of Agricultural Technology, King Mongkut's Institute of \\ Technology Ladkrabang, Bangkok 10520, Thailand
}

${ }^{3}$ Nakornratchasima Livestock Research and Breeding Center, Bureau of Animal Husbandry and Genetic Improvement, Department of Livestock Development (DLD), Khanongphra, Pakchong, Nakornratchasima 30130, Thailand

\begin{abstract}
The objective of this study was to investigate physicochemical characteristics and collagen solubility of pigs fed with dietary ractopamine (RAC) during finishing period. Thirty of three-way crossbred pigs (Large White $\times$ Landrace $\times$ Duroc) with an initial bodyweight $(\mathrm{BW})$ of $18.0 \pm 0.5 \mathrm{~kg}$ were randomly assigned to one to three dietary RAC inclusions $(0,20$, or $40 \mathrm{mg} / \mathrm{kg}$ ) fed during finishing period $(60-100 \mathrm{~kg}$ BW). Each group consisted of five gilts and five barrows. After 109 day of raising period, all pigs were slaughtered at the average weight of $100 \mathrm{~kg}$. Longissimus dorsi muscle (LD) was taken from each carcass after overnight chill and analyzed for physical characteristics, chemical composition, and collagen solubility. The LD from pigs fed $40 \mathrm{mg} / \mathrm{kg}$ of RAC had lower a* value $(\mathrm{p}<0.01)$ than others. Pigs fed with $40 \mathrm{mg} / \mathrm{kg}$ of RAC had higher Warner-Bratzler shear force $(\mathrm{p}<0.05)$ than pigs fed without RAC. Pigs fed with dietary RAC had lower glycogen content than control $(p<0.01)$. While other chemical compositions and collagen solubility of LD were not affected by dietary RAC $(p>0.05)$. Gilts had larger muscle fibers $(p<0.01)$, lower glycogen content $(p<0.05)$, higher content of insoluble collagen $(p<0.05)$, total collagen $(p=0.054)$, and collagen solubility $(p=0.054)$ than barrows.
\end{abstract}

\section{Introduction}

Using ractopamine as growth-promoting in pig industry, it is approved that the feed efficiency and carcass quality have been improved while it has affected meat quality. Such as the studies of [1] showed that RAC increased carcass lean content and acted directly to nutrients from fat deposition toward protein deposition in finishing pigs. RAC has been used to improve feed efficiency and increase leanness [2]. However, the study of [3] and [2] reported that dietary RAC supplemented increased toughness of pork. The addition of RAC at the level of $5 \mathrm{ppm}$ in diet slightly reduced tenderness of pork [4]. As well as, the study of [5] reported that RAC supplemented at $10 \mathrm{mg} / \mathrm{kg}$ in pig diet had negatively impacted on tenderness.

Color of fresh meat is one of the most important traits influencing consumers' purchasing decisions [6]. The amount of glycogen at slaughter affects meat quality by influencing post mortem lactic acid production and $\mathrm{pH}$ decline [7]. The effect of $\mathrm{pH}$ on water holding capacity and color of meat in pork has been widely documented $[8,9]$. The other important attribute in terms of meat quality is tenderness [10]. Collagen content and its solubility had an impact on meat tenderness [11, 12]. Due to glycogen content and collagen solubility had significant effects on meat quality, but the information of these traits in pig fed with RAC is still limit. Therefore, the objective of this study was to investigate the effect of RAC supplement diet on physicochemical characteristics and collagen solubility in finishing barrows and gilts.

\section{Materials and Methods}

\subsection{Animals}

The experimental procedure on animal care and use was approved by the Institutional Animal Care and Use Committee of King Mongkut's Institute of Technology Ladkrabang (AGRI-KMITL003/2015).

A total of thirty 3-way crossbred pigs (Large White $\mathrm{X}$ Landrace X Duroc) with an average initial bodyweight of $18.0 \pm 0.5 \mathrm{~kg}$ were randomly assigned to 1 to 3 dietary inclusions of RAC $\left(0,20\right.$, or $40 \mathrm{mg} / \mathrm{kg}$; Paylean $\left.{ }^{\mathrm{TM}}\right)$. Each group consisted of five gilts and five barrows. Animals were fed ad libitum with 18, 16, and $14 \%$ protein diet during starting (20 to $40 \mathrm{~kg}$ ), growing (40 to $60 \mathrm{~kg}$ ), and 
finishing period (60 to $100 \mathrm{~kg}$ ), respectively. RAC was supplemented to diet during finishing period. Pigs were raised under the same condition in individual pens for 109 days. After the raising period, all pigs were slaughtered at the average weight of $100 \mathrm{~kg}$.

\subsection{Physical characteristics}

The $\mathrm{pH}$ at $45 \mathrm{~min}$ and $24 \mathrm{~h}$ post mortem were measured in duplicate directly at the 10 to $11^{\text {th }}$ ribs of the left side carcass using $\mathrm{pH}$ meter equipped with a spear tip glass electrode (Model SG2 - ELK Seven Go ${ }^{\mathrm{TM}}$, Mettler Toledo International Inc., China). After 24 hours chilling, Longissimus dorsi (LD) was removed from the right side of each carcass for further analysis.

Drip loss was determined in duplicate as the weight loss during suspension of meat samples (weighing approximately $100 \mathrm{~g}$ ) in a closed plastic bag over 48 hour at $4{ }^{\circ} \mathrm{C}$ [13]. Drip loss was expressed as a percentage relative to the initial weight. For meat color measurement, LD muscle was cut into 3 -cm-thick slice and allowed to bloom for $30 \mathrm{~min}$ before measuring CIE $\mathrm{L}^{*}, \mathrm{a}^{*}$, and $\mathrm{b}^{*}$ color values using a Minolta Chromameter CR-300 (Minolta Camera Co., Japan; Illuminant D65). For measuring cooking loss, two pieces of 3-cm-thick slices obtained from each LD muscle were weighed, placed into high-density polyethylene bag, heat sealed, and then cooked in a water bath set at $80^{\circ} \mathrm{C}$ for $30 \mathrm{~min}$ or until internal temperature of meat sample reached $70^{\circ} \mathrm{C}$. After cooked samples were cooled down by running tap water to room temperature before weighing then cooking loss percentage was estimated by calculating the difference between before and after cooking weight. Cooked samples were cut along the muscle fiber into 10 cubes $\left(1 \times 1 \times 3 \mathrm{~cm}^{3}\right)$. Shear force values were determined using a Warner-Bratzler shear attachment on a texture (model 2519-104, Instron ${ }^{\circledR}$, Norwood, MA, USA) equipped with a $50 \mathrm{~kg}$ load cell using $200 \mathrm{~mm} / \mathrm{min}$ crosshead speed.

Muscle fiber diameter was determined from 200 muscle fibers of 2 cubes $\left(2 \times 2 \times 2 \mathrm{CM}^{3}\right)$ of each muscle sample using $4 \mathrm{X}$ compound microscope equipped with Dino-Eye eyepiece camera to capture images and subsequently evaluated with Dino Capture version 2.0 software (AnMo Electronics Corporation, New Taipei City, Taiwan) [14]. Sarcomere length data were determined from 2 cubes $\left(2 \times 2 \times 2 \mathrm{CM}^{3}\right)$ of muscle samples according to [15]. The average of 30 sarcomere lengths was acquired from each sample.

\subsection{Chemical characteristics}

After 24 hours chilling, $100 \mathrm{~g}$ of LD muscle from the right side of each carcass was collected and kept in vacuum bag at $-20^{\circ} \mathrm{C}$ until evaluating moisture, fat, and collagen content. Moisture and crude fat content of meat samples were performed following the procedures of the Official Association of Official Analytical Chemists (AOAC) method [16]. For measuring glycogen content, $50 \mathrm{~g}$ of LD muscle from the left side of each carcass was collected within 1 hour post mortem then immediately frozen in liquid nitrogen and stored at $-40^{\circ} \mathrm{C}$ until measuring glycogen content following the method of [17]. Soluble, insoluble, and total collagens were determined by the method of $[16,18]$.

\subsection{Statistical analysis}

Analyses of variance was generated by using the GLM procedure (SAS Inst. Inc., Cary, NC) with RAC and sex as the main effects with interaction. Least squares means were separated using the probability of difference option (PDIFF), and the results were considered significant difference when $\mathrm{p}<0.05$.

\section{Results and Dicussion}

\subsection{Physical characteristics}

The $\mathrm{pH}$ at $45 \mathrm{~min}$ and $24 \mathrm{~h}$ postmortem were not different among RAC supplemented levels and between sexes in the present study (Table 1). The LD muscles from pigs fed with 0 and $20 \mathrm{mg} / \mathrm{kg}$ of RAC had higher $a^{*}$ value than pigs fed with $40 \mathrm{mg} / \mathrm{kg}$ of RAC $(\mathrm{p}<0.01)$ while $L^{*}$ and $b^{*}$ values were not affected by dietary RAC ( $p>0.05)$. Level of RAC supplemented and sex had no affected on drip loss and cooking loss percentage ( $p>0.05$ ). Pigs fed with $0 \mathrm{mg} / \mathrm{kg}$ of RAC had lower WBSF than pigs fed with $40 \mathrm{mg} / \mathrm{kg}$ of RAC $(\mathrm{p}<0.05)$ at day 1 and day 5 post mortem. While WBSF of pigs fed with $20 \mathrm{mg} / \mathrm{kg}$ of RAC showed no significant difference from others $(p>0.05)$. The level of supplemented RAC and sex had no significant effect on sarcomere length and muscle fiber diameter. However, barrows had shorter $(p<0.05)$ muscle fiber diameter than gilts. There were no interaction between RAC level in diet and sex on physical characteristics in LD muscles in the present study $(\mathrm{p}>0.05)$.

As the $\mathrm{pH}$ at $45 \mathrm{~min}$ and 24 hour postmortem were not different among RAC supplemented levels and between sexes in the present study. Several studies showed that there was no significant difference in muscle $\mathrm{pH}$ in $\mathrm{RAC}$ treated pigs $[2,3,4,5]$. Also, the LD muscles of pigs fed with 0 and $20 \mathrm{mg} / \mathrm{kg}$ RAC had higher $\mathrm{a}^{*}$ value than pigs fed with $40 \mathrm{mg} / \mathrm{kg}$ of RAC while $\mathrm{L}^{*}$ and $\mathrm{b}^{*}$ values were not affected by dietary RAC in the present study. The study of $[1,2,3,5]$ demonstrated no effect of RAC feeding on $\mathrm{L}^{*}$ value which was similar to this study. In contrast to this study, $[1,3,4]$ reported the lower $b^{*}$ value of $L D$ in RAC treated pigs. While [5] did not detect an effect of feeding RAC on $b^{*}$ values of the LD. Similar to this study, a persistent reduction in $\mathrm{a}^{*}$ values has been reported in RAC fed pigs $[1,2,4,5]$. The lower $a^{*}$ values indicate less oxymyoglobin in the muscle [1]. As described by [19], RAC caused an increase in the proportion of white fibers. A decrease in myoglobin content in muscle is suggested by this shift; because white fibers have less myoglobin than red and intermediate fibers. Several studies reported that RAC affected muscle fiber distribution. As in the study of [20], RAC supplemented at 20 or $60 \mathrm{mg} / \mathrm{kg}$ did not affect the percentage of type I and IIA fibers but the percentage of type IIAX fibers 
were decreased while type IIB fibers were increased. Furthermore, the researchers reported a strong significant negative correlation $(\mathrm{R}=-0.768)$ between type IIAX fibers and type IIB fibers. [21] also demonstrated that RAC supplemented at $20 \mathrm{mg} / \mathrm{kg}$ caused an increase in the mRNA expression of type IIB fibers at the expense of type IIX fibers while the expression of type I fibers was unaffected.

Table 1 Physical characteristics of pork from barrows and gilts fed with and without RAC

\begin{tabular}{|c|c|c|c|c|c|c|c|c|c|}
\hline \multirow[t]{2}{*}{ Traits } & \multicolumn{3}{|c|}{ RAC (R) } & \multicolumn{2}{|c|}{$\operatorname{Sex}(\mathrm{S})$} & \multirow[t]{2}{*}{ RMSE } & \multicolumn{3}{|c|}{ P-value } \\
\hline & 0 & 20 & 40 & Gilt & Barrow & & $\mathrm{R}$ & $\mathrm{S}$ & RXS \\
\hline $\mathrm{pH}_{45}$ & 6.15 & 5.97 & 6.14 & 6.02 & 6.15 & 0.37 & 0.485 & 0.361 & 0.986 \\
\hline $\mathrm{pH}_{24}$ & 5.49 & 5.47 & 5.52 & 5.46 & 5.52 & 0.10 & 0.568 & 0.166 & 0.785 \\
\hline \multicolumn{10}{|l|}{ Color } \\
\hline $\mathrm{L}^{*}$ & 59.66 & 58.91 & 58.18 & 57.80 & 60.04 & 4.70 & 0.818 & 0.238 & 0.181 \\
\hline$a^{*}$ & $8.26^{\mathrm{a}}$ & $7.14^{\mathrm{a}}$ & $5.84^{\mathrm{b}}$ & 7.48 & 6.67 & 1.21 & 0.002 & 0.101 & 0.401 \\
\hline $\mathrm{b}^{*}$ & 3.35 & 2.04 & 1.58 & 2.26 & 2.39 & 1.68 & 0.122 & 0.843 & 0.138 \\
\hline $\mathrm{DL}^{1}(\%)$ & 6.68 & 6.54 & 6.61 & 7.39 & 5.83 & 2.38 & 0.991 & 0.086 & 0.091 \\
\hline \multicolumn{10}{|l|}{$\mathrm{CL}^{2}(\%)$} \\
\hline Day 1 & 20.05 & 19.41 & 19.83 & 19.95 & 19.58 & 2.81 & 0.876 & 0.719 & 0.198 \\
\hline Day 5 & 20.39 & 20.12 & 19.40 & 20.42 & 19.51 & 2.42 & 0.646 & 0.317 & 0.137 \\
\hline \multicolumn{10}{|l|}{$\mathrm{SF}^{3}(\mathrm{~kg})$} \\
\hline Day 1 & $3.73^{x}$ & $4.17^{x y}$ & $4.71^{y}$ & 4.27 & 4.14 & 0.78 & 0.032 & 0.654 & 0.168 \\
\hline Day 5 & $3.95^{x}$ & $4.24^{x y}$ & $4.79^{y}$ & 4.41 & 4.24 & 0.70 & 0.039 & 0.524 & 0.206 \\
\hline $\mathrm{SL}^{4}(\mu)$ & 1.70 & 1.71 & 1.71 & 1.71 & 1.71 & 0.06 & 0.934 & 0.866 & 0.225 \\
\hline $\operatorname{MD}^{5}(\mu)$ & 79.76 & 86.04 & 80.43 & $87.20^{\mathrm{a}}$ & $76.96^{\mathrm{b}}$ & 7.02 & 0.111 & 0.0005 & 0.276 \\
\hline
\end{tabular}

${ }^{a, b}$ within a row and main effect, least squares means with different superscripts differ $(\mathrm{p}<0.01)$ $x, y$ within a row and main effect, least squares means with different superscripts differ $(p<0.05)$ ${ }^{1-5} \mathrm{DL}=$ Drip loss, $\mathrm{CL}=$ Cooking loss, $\mathrm{SF}=$ Shear force, $\mathrm{SL}=$ Sarcomere length, $\mathrm{MD}=$ Muscle fiber diameter

Level of RAC supplemented and sex had no affected on drip loss and cooking loss percentage in the current study. However, the study of [4] reported that barrow had higher drip loss at 24 and 48 hour post mortem than gilt. The results from $[3,4,5]$ showed that there were no difference of drip loss and cooking loss between pigs fed with and without RAC supplemented. The study of [1] found the higher drip loss percentage of $20 \mathrm{mg} / \mathrm{kg}$ of RAC than control but there was not different in cooking loss among treated RAC. In this study, pigs fed with $40 \mathrm{mg} / \mathrm{kg}$ of RAC had higher WBSF than pigs fed without RAC while pigs fed with $20 \mathrm{mg} / \mathrm{kg}$ of RAC showed no significant difference compared to pigs fed with 0 and $40 \mathrm{mg} / \mathrm{kg}$ of RAC. From the study of $[2,3,5]$, pigs fed with more than $10 \mathrm{mg} / \mathrm{kg}$ RAC had higher WBSF and more toughness. Moreover, [2] reported that pigs fed with RAC showed slower protein degradation rate than control pigs. LD muscle from pigs fed with RAC tended to have a slower protein degradation rate than control which indicated by the delayed emerging of $14-45 \mathrm{kDa}$ polypeptides. The less postmortem degradation of myofibrillar protein may be responsible for increasing in toughness of pork from pigs fed with RAC.

There were no significant difference on sarcomere length and muscle fiber diameter due to RAC supplemented level and sex in this study. However, barrows had shorter muscle fiber diameter than gilts. This could be due to gilts had higher proportion of type IIb fiber than barrows. [22] reported that gilts had a larger muscle fiber especially in type IIb fibers than barrows. According to the length of sarcomere, when the muscle contracted it would have shorter sarcomere length then meat would likely to be tougher. $\beta$-agronist did not affect the range of sarcomere length in Lambs [23] and in cattle [24]. In the present study, sarcomere length of pig fed with different levels of RAC were not significantly different thus RAC did not affected muscle contraction. There is controversial for the effect of gender on muscle fiber size. The studies of [25] reported larger fibers in gilts than in barrows, whereas [26] reported there was no effect of gender on muscle fiber size of Longissimus muscle.

\subsection{Chemical composition and collagen solubility}

The percentage of moisture and crude fat from LD of pigs fed with different RAC levels and different sexes were not significant different (Table 2). Pigs fed without RAC had higher $(p<0.05)$ glycogen content than pigs fed with 20 and $40 \mathrm{mg} / \mathrm{kg}$ of RAC. The effect of sex on glycogen content was found in this study as barrows had higher glycogen content than gilts $(p<0.05)$. RAC levels had no effect on collagen content and collagen solubility $(\mathrm{p}>0.05)$. Gilts had higher insoluble collagen $(\mathrm{p}<0.05)$, total collagen $(\mathrm{p}=0.054)$, and percentage of collagen solubility $(p=0.054)$ than barrows. There were no interaction between RAC level in diet and sex on chemical composition and collagen solubility in LD muscles in the present study ( $p>0.05)$.

Table 2 Chemical composition and collagen characteristics of pork from barrows and gilts fed with and without RAC

\begin{tabular}{|c|c|c|c|c|c|c|c|c|c|}
\hline \multirow[t]{2}{*}{ Traits $^{1}$} & \multicolumn{3}{|c|}{ RAC (R) } & \multicolumn{2}{|c|}{$\operatorname{Sex}(\mathrm{S})$} & \multirow[t]{2}{*}{ RMSE } & \multicolumn{3}{|c|}{ P-value } \\
\hline & 0 & 20 & 40 & Gilt & Barrow & & $\mathrm{R}$ & $\mathrm{S}$ & RXS \\
\hline $\mathrm{M}$ & 73.09 & 71.96 & 73.58 & 72.80 & 72.95 & 1.95 & 0.182 & 0.832 & 0.073 \\
\hline $\mathrm{EE}$ & 2.13 & 2.41 & 2.23 & 2.00 & 2.51 & 0.70 & 0.689 & 0.059 & 0.531 \\
\hline Gly & $40.10^{\mathrm{a}}$ & $22.56^{\mathrm{b}}$ & $16.36^{\mathrm{b}}$ & $22.10^{x}$ & $30.94^{y}$ & 9.26 & $<0.0001$ & 0.022 & 0.081 \\
\hline SC & 0.42 & 0.36 & 0.35 & 0.38 & 0.37 & 0.11 & 0.357 & 0.800 & 0.731 \\
\hline IC & 2.66 & 2.95 & 3.08 & $3.27^{x}$ & $2.53^{y}$ & 0.94 & 0.598 & 0.042 & 0.360 \\
\hline $\mathrm{TC}$ & 3.08 & 3.32 & 3.43 & 3.65 & 2.90 & 1.02 & 0.731 & 0.054 & 0.375 \\
\hline CS & 13.82 & 11.25 & 12.86 & 10.69 & 14.56 & 5.23 & 0.550 & 0.054 & 0.356 \\
\hline
\end{tabular}

a,b within a row and main effect, least squares means with different superscripts differ $(\mathrm{p}<0.01)$ ${ }^{1} \mathrm{M}=\%$ Within a row and main effect, least squares means with different superscripts differ $(\mathrm{p}<0.05)$ $\mathrm{M}=\%$ Moisture $; \mathrm{EE}=\%$ Ether extract $; \mathrm{Gly}=$ Glycogen content $(\mu \mathrm{mol} / \mathrm{g}) ; \mathrm{SC}=$ Soluble collag
$(\mathrm{mg} / \mathrm{g}) ; \mathrm{IC}=$ Insoluble collagen $(\mathrm{mg} / \mathrm{g}) ; \mathrm{TC}=$ Total collagen $(\mathrm{mg} / \mathrm{g}) ; \mathrm{CS}=\%$ Collagen solubility

Crude fat percentage of LD was not affected by dietary RAC in the present study. In agreement with the results reported by $[3,5]$. The study of $[5]$ also reported that there was no effect of sex on fat content which was consistent with this study. Pigs fed without RAC had higher glycogen content than pigs fed with dietary RAC in the present study. In agreement with [27] who reported that the amount of glycogen stored in skeletal muscle tissue of the pigs fed without RAC higher than pigs fed with RAC. [21] explained the possibility that 
chronic supplementation of RAC leads to the decline of glycogen levels, it may be due to the needs for energy increased associated with increased muscle growth. Barrow had higher glycogen content than gilt in this study. In contrast to [28] reported that gender had no effect on glycogen content neither at $45 \mathrm{~min}$ nor at 24 hour postmortem.

Dietary RAC levels did not impact collagen content and collagen solubility in this study. Similar to the current study, there were no effect of RAC on collagen content and collagen solubility in heifer [29] and in steer [30]. In this study, gilts had significant higher content of insoluble collagen and tended to have higher content of total collagen and percentage of collagen solubility than barrows. In contrast to [30] who reported that gender had no significant effect on total collagen content and collagen solubility. The average of total collagen $4 \mathrm{mg} / \mathrm{g}$ in Longissimus muscle reported by [31] was slightly higher than the results in this study which were 2.90 and $3.65 \mathrm{mg} / \mathrm{g}$ for barrow and gilt, respectively. While the range of $10.69-14.56 \%$ of collagen solubility in the present study was in the similar range, $11-13 \%$, as reported by [31].

\section{Conclusion}

The LD from pigs fed with $40 \mathrm{mg} / \mathrm{kg}$ of RAC was less redness than LD from others. Pigs fed with 40 $\mathrm{mg} / \mathrm{kg}$ of RAC had tougher LD than control. Dietary RAC decreased glycogen content in LD muscle but not affected other chemical composition and collagen solubility. Compared to barrows, gilts had lager muscle fiber, lower glycogen content, and higher insoluble collagen content, also tended to have higher total collagen content and collagen solubility.

\section{Acknowledgments}

This research was supported by a grant of the National Bureau of Agricultural Commodity and Food Standards, Thailand.

\section{References}

1. S.N. Carr, D.J. Ivers, D.B. Anderson, D.J. Jones, D.H. Mowrey, M.B. England, J. Killefer, P.J. Rincker, F.K. McKeith, J Anim Sci 83, 2886-93 (2005a)

2. Y.L. Xiong, M.J. Gower, C. Li, C.A. Elmore, G.L. Cromwell, M.D. Lindemann, Meat Sci 73, 600-4 (2006)

3. S.N. Carr, P.J. Rincker, J. Killefer, D.H. Baker, M. Ellis, F.K. McKeith, J Anim Sci 83, 223-30 (2005b)

4. J.F. Patience, P. Shand, Z. Pietrasik, J. Merrill, G. Vessie, K.A. Ross, A.D. Beaulieu, Can J Anim Sci 89, 53-66 (2009)

5. N.B. Athayde, O.A. Dalla Costa, R.O. Roca, A.L. Guidoni, C.B. Ludtke, G.J.M.M. Lima, J Anim Sci 90, 4604-10 (2012)

6. S.J. Moeller, R.K. Miller, K.K. Edwards, H.N. Zerby, K.E. Logan, T.L. Aldredge, C.A. Stahl, M. Boggess, J.M. Box-Steffensmeier, Meat Sci 84, 14-22 (2010)

7. G. Monin, P. Sellier, Meat Sci 13, 49-63 (1985)
8. J.L. Melody, S.M. Lonergan, L.J. Rowe, T.W. Huiatt, M.S. Mayes, E. Huff-Lonergan, J Anim Sci 82, 1195-1205 (2004)

9. E. Huff-Lonergan, S.M. Lonergan, Meat Sci 71, 194 204 (2005)

10. M. Maltin, D. Balcerzak, R. Tilley, M. Delday, Proc Nutr Soc 62, 337-47 (2003)

11. S.H. Fang, T. Nishimura, K. Takahashi, J Anim Sci 77(1), 120-30 (1999)

12. T.L. Wheeler, S.D. Shackelford, M. Koohmaraie, J Anim Sci 78(4), 958-65 (2000)

13. K. Honikel, Meat Sci 49, 447-57 (1998)

14. H.J. Tuma, J.H. Venable, P.R. Wuthier, R.L. Henrickson, J Anim Sci 21, 33-6 (1962)

15. H.R. Cross, R.L. West, T.R. Dutson, Meat Sci 5(4), 261-266 (1981)

16. W. Horwitz, Official methods of analysis of AOAC International 17th ed. (AOAC International, 2002)

17. C.E. Dreiling, D.E. Brown, L. Casale, L. Kelly, Meat Sci 20,167-77 (1987)

18. F. Hill, J Food Sci 31,161-66 (1966)

19. J.L. Aalhaus, A.L. Schaefer, A.C. Murray, S.D.M. Jones, Meat Sci 31(4), 397-409 (1992)

20. F.F.S. Depreux, A.L. Grant, D.B. Anderson, D.E. Gerrard, J Anim Sci 80, 1888-94 (2002)

21. A.M. Gunawan, B.T. Richert, A.P. Schinckel, A.L. Grant, D.E. Gerrard, J Anim Sci 85, 2115-24 (2007)

22. C. Larzul, L. Lefaucher, P. Ecolan, J. Gogue, A. Talmant, P. Sellier, P. Le Roy, G. Monin, J Anim Sci 75 (12), 3126-37 (1997)

23. Y.B. Lee, H. Jung, Y.S. Kim, R.H. Dalrymple, J Anim Sci 66 (Suppl. 1), 279 (1988)

24. I. Girard, J.L. Aalhus, J.A. Basarab, I.L. Larsen, H.L. Bruce, Can J Anim Sci 92, 175-88 (2012)

25. C. Larzul, L. Lefaucher, P. Ecolan, J. Gogue, A. Talmant, P. Sellier, P. Le Roy, G. Monin, J Anim Sci 75 (12), 3126-37 (1997)

26. G. Bee, J Anim Sci 82, 826-36 (2004)

27. T.S. Araujo, L.C.J. Porto, E.G. Mario, L.J. Pereira, M.S.D.S. Ferreira, M.G. Zangeronimo, M.H. Napimoga, L.M. Botion, R.V. De Sousa, Turk J Vet Anim Sci 38, 54-62 (2004)

28. C. Terlouw, A. Berne, T. Astruc, Livest Sci 122 , 199-213 (2009)

29. S.M. Ebarb, K.J. Phelps, J.S. Drouillard, K.R. Maddock-Carlin, M.A. Vaughn, D.D. Burnett, J.A. Noel, C.L. Van Bibber-Krueger, C.B. Paulk, D.M. Grieger, J.M. Gonzalez, J Anim Sci 95(3),1219-31 (2017)

30. P.E. Strydom, L. Frylinck, J.L. Montgomery, M.F. Smith, Meat Sci 81, 557-64 (2009)

31. J.A. Correa, L. Faucitano, J.P. Laforest, J. Rivest, M. Marcoux, C. Gariepy, Meat Sci 72(1), 91-9 (2006) 